\title{
Winter Meeting 1997
}

The Winter Meeting was held at the Cardiff International Arena, Cardiff, on 21-24 January 1997.

\section{Business Meeting}

The Business Meeting was held on 22 January 1997 and attended by 69 Members of the College.

\section{Minutes}

The Minutes of the 1996 Winter Business Meeting, held on the 25 January 1996 at the Moat House International Hotel, Stratford-upon-Avon, were approved and signed.

\section{Election of Honorary Fellows}

The following were elected to the Honorary Fellowship: Dame Fiona Caldicott, Dr Ismond Rosen, Professor Sir Michael Rutter, Dr Robert van Voren and Ms Marjorie Wallace.

\section{Registrar's report}

It is now six months since the College passed the Resolution critical of the implementation of community care. Members will be aware that the King's Fund have recently confirmed our findings. What have the Officers done since the Summer Meeting?

There have been meetings and correspondence between the senior Officers and officials in the Department of Health and the President, and there will be a meeting with the Secretary of State early next month to discuss progress. Regional offices of the NHSE have agreed to a closer relationship with the College's reorganised Divisions, which will allow us to give advice on Health Authority purchasing plans. This will be a voluntary arrangement and Divisions will be only one source of advice to Regional Offices. Nevertheless, with the centre shrinking it is vital for the College to have its voice heard in the Regions.

An early result of this collaboration will be a series of Regional/Divisional conferences in England, possibly in the autumn of this year. These will bring together psychiatrists and purchasers to discuss the future shape of the services in each Region. In addition, there will be a complementary series of conferences on manpower and training, co-sponsored by the Sainsbury Centre. This will build on the successful workshop on manpower which took place recently.

The CRU, with partners in the RCN, BGS and OPM, has successfully bid to take over the work of the HAS/DAS, and a detailed proposal for the relationship between the new organisation and the College will be brought to Council next week.

The timetable for elections and boundary changes needed to effect the Divisional, Faculty and Section reorganisation will be presented to the next Council. We believe it will be possible to achieve this by the time of the Annual Meeting in 1997. The first meeting has taken place of the new Special Committee on University Psychiatry and $a$ ballot for Chairman is in progress.

Vigorous representations to Parliament have been made over the Crime (Sentences) Bill which proposes a hybrid order for mentally disordered offenders. Interviews have been held with Junior Ministers and officials in the Home Office, joint Parliamentary briefings have been produced with the Law Society, and our new Parliamentary Liaison Officer, Louis Gargan, has been monitoring the passage of the Bill, suggesting amendments and offering assistance to MPs and Peers.

The GMSC last year produced a worrying paper seeking to restrict the responsibilities of GPs for the care of the mentally ill. The President and Section representatives will shortly be meeting the GMSC to explore our concerns in more detail and we continue to work on a series of shared care documents with our colleagues in the RCGPs.

A proposal for a joint working group on drug misuse with the RCP has been approved by RCP's Council and will be considered by our Council next week.

The NHS Review of Psychotherapy Services has been received in the College and welcomed by the Psychotherapy Section.

Council has recently approved the reports:

Meeting the Mental Health Needs of Adults with Mild Learning Disability

Handbook on Pertnatal, Maternal Mental Health Services

Ethical Guidance for the Treatment of People with a Long-term Mental Disorder

Council will be considering these further reports:

Joint Report with RCS on the Psychological Care of Surgical Patients 


\section{THE COLLEGE}

Report of the Working Group on the Association between Antipsychotic Drugs and Sudden Death

Guidelines to Good Practice in the use of Behavioural and Cognitive Treatments Benzodiazepines and Dependence

Recovered Memories of Sexual Abuse
Finally, it is now quite clear that review of the Mental Health Act is on the agenda for the next Parliamentary session. All Faculties, Sections, Special Interest Groups, Divisions and Committees have been urged to begin to consider changes in the Act which they believe to be necessary - thinking as radically as possible. 